\title{
PENINGKATAN USAHA TERNAK KAMBING DI KELOMPOK TANI SUMBER SARI DALAM ANALISIS EKONOMI PENDAPATAN
}

\author{
S. Rusdiana dan Rijanto Hutasoit \\ Pusat Penelitian dan Pengembangan Peternakan Jl. Pajajaran KVE.59 Bogor \\ Loka Penelitan Kambing Potong Sei Putih Medan No.1 Galang Medang-Sumatera Utara \\ E-mail: s.rusdiana20@gmail.com
}

\begin{abstract}
This research was conducted at the District High King shavings District of North Sumatra Province. The purpose of the study was to determine the increase in goat farming goat farmer groups in the analysis of pollen sources of income. The study was conducted in the village of Sumber High King and High King of Hope in District District shavings, each study site has the same agro-ecosystems. The study was conducted by the method by filling in a questionnaire survey using kuwesioner and structured interviews with 15 respondents farmers and 15 farmer groups koopertor non-cooperators, in November-December 2012, according to the information from the Department of Agricultural Extension and local farming population criteria goats and primary data secondary data collected was analyzed using descriptive tabulation and analysis of the economy. The results of the research effort goat raising net income amounted Rp.8.411.168 Koopertor, 83/tahun, B/C ratio of 1.4, and goat enterprises are non Cooperators sebsar Rp. 1,644,051.24/year, B/C ratio of 1.2. This can increase the income of farmers in maintaining the well-being of families and the need for the application of technological innovations introduced so that a more commercial farming goats and goats can be sustained presence in times to come.
\end{abstract}

Keywords: Improvement, businesses goat farmer groups cider revenue sources

\begin{abstract}
Abstrak: Penelitian ini dilakukan di Kecamatan Tinggi Raja Kabupaten Asahan Propinsi Sumatera Utara. Tujuan penelitian adalah untuk mengetahui peningkatan usaha ternak kambing di kelompok peternak kambing sumber sari dalam analisis pendapatan. Penelitian dilakukan di Desa Tinggi Raja dan Desa Sumber Harapan di Kecamatan Tinggi Raja Kabupaten Asahan, masing-masing lokasi penelitian mempunyai agroekosistem yang sama. Penelitian dilakukan dengan metoda survei dengan mengisi daftar pertanyaan menggunakan kuwesioner dan wawancara berstruktur terhadap 15 responden petani kelompok koopertor dan 15 petani non kooperator, pada bulan Nopember-Desember 2012, sesuai informasi dari Dinas Penyuluh Pertanian dan Peternakan setempat dengan kriteria populasi ternak kambing Data primer dan data sekunder yang terkumpul kemudian dianalisis dengan menggunakan tabulasi secara deskritif serta analisis ekonomi. Hasil penelitian dari usaha pemeliharaan ternak kambing pendapatan bersih secara Koopertor sebesar Rp.8.411.168,83/tahun, B/C ratio 1,4, dan usaha kambing secara Non Kooperator sebsar Rp. 1.644.051,24/tahun, B/C ratio 1,2. Hal ini dapat meningkatkan pendapatan petani dalam mempertahankan kesejahteraan keluarganya dan perlu adanya penerapan introduksi inovasi teknologi sehingga usaha ternak kambing lebih komersial dan dapat dipertahankan keberadaan ternak kambing di masa-masa yang akan datang.
\end{abstract}

Kata kunci: Peningkatan, usaha kambing, kelompok tani sumber sari pendapatan 


\section{PENDAHULUAN}

Prospek pengembangan usaha peternakan kambing di Indonesi berpeluang besar, serta manfaatnya sangat banyak terhadap semua arah, diantaranya kecukupan daging, penghasilan bagi peternak, penambahan devisa bagi negara dan lain sebagainya. strategi dalam perluasan pengembangan ternak kambing dan memperluas pangsa pasar, memberikan keuntungan bagi usaha pengembangan ternak kambing. Populasi ternak kambing di Indonesia tercatat sekitar 15.655.739 ekor Statistik Pertanian (2010) yang tersebar di beberapa wilayah seperti Propinsi Sumatera Utara 619.940 ekor (21,92\%), di Kecamatan Tinggi Raja sekitar 1.684 ekor $(8,19 \%)$ Statistik Kabupaten Asahan (2011). Sistem pemeliharaan ternak kambing di Indonesia sekitar $(80 \%)$ masih diusahakan oleh petani kecil (peternakan rakyat) yang berkembang di wilayah pedesaan. Usaha ternak kambing merupakan komponen penting dalam usahatani penduduk pedesaan karena pemeliharaan ternak kambing dalam skala kecil dapat membantu perekonomian rakyat di pedesaan dengan pemanfaatan sumberdaya alam yang tersedia di sekitarnya.

Dari berbagai kelebihan dan fungsi ternak kambing merupakan peluang bagi pengembangan peternak, pemerintah dan swasta dapat bekerjasama dalam mengembangkan dan meningkatkan populasi ternak kambing dalam rangka meningkatkan peningkatan pendapatan peternak disamping produksi daging lokal. Ternak kambing dapat dikembangkan hampir disemua kondisi agroekosistem di Indonesia, ternak ambing memiliki harga jual yang cukup tinggi, menjadikan daya tarik tersendiri dari pelaku usaha untuk memasuki usaha kambing dengan harapan memperoleh keuntungan dan juga sebagai investasi jaminan kebutuhan sehari-hari bagi petani ternak di pedesaan Yusdja (2004). Potensi lahan untuk pengembangan peternakan kambing (ruminansia) harus dimanfaatkan sedemikian rupa sehingga dapat menghasilkan keuntungan yang sepadan dengan hasil kerja keras yang dilakukan oleh petani, bila hal tersebut di laksanakan maka tidak mubajir

Disamping itu ternak kambing adalah salah satu komoditas yang dipelihara oleh para peternak yang berfungsi sebagai sumber protein hewani bagi masyarakat, sebagai tabungan, tambahan penghasilan, pengisi waktu, pemanfaatan pekarangan dan kotorannya bisa dijadikan sebagai pupuk kandang. Ternak kambing yang ada di Indonesia termasuk yang ada di Sumatera Utara (Kecamatan Tinggi Raja), lebih sering digembalakan atau diabur oleh pemiliknya. Mengingat sifat dan reproduksinya yang cepat dan adaptasinya yang tinggi terhadap berbagai kondisi agroekosistem maka ternak kambing banyak dipelihara di perdesaan Simom, (2010). Usaha ternak kambing merupakan salah satu sumber pertumbuhan baru dalam menunjang pendapatan petani disamping usaha pertanian lainnya.

Tantangan yang sering dihadapi dalam pengembangan usaha ternak adalah kemampuan untuk memenuhi kebutuhan pangan melalui perbaikan produksi dan kualitas ternak dengan jalan pembinaan kepada petani yang daerahnya potensial. Saenab et al., (2005), Bamualim. (2010) dan Tatang.(.2003), berpendapat yang sama bahwa, salah satu faktor penentu dalam keberhasilan usaha dari ternak ruminansia adalah jaminan ketersediaan tanaman pangan dan hijauan pakan terak yang berkualitas. Ketersediaan lahan pertanian, lahan kosong perkebunan, tegalan, sawah dan ladang, merupakan lahan yang potensial untuk menyediakan hijauan pakan ternak baik rumput atau berbagai limbah pertanian yang dapat dimanfaatkan untuk pengembangan usaha ternak ruminansia Syamsu.(2003)

Pengembangan usaha ternak kambing dipandang sangat cocok dalam kondisi lahan pertanian, karena ternak kambing dikenal mudah beradaptasi pada berbagai kondisi agroekosistem pedesaan serta merupakan usaha komplementer dalam suatu sistim pertanian tanaman pangan Winarso, (2010). Secara biologis ternak kambing cukup produktif dan adaptif dengan kondisi lingkungan setempat, sehingga memudahkan pengembangannya. Pengembangan ini dapat lebih diarahkan keluar Jawa mengingat besarnya sumberdaya alam di daerah-daerah tersebut cukup potensial. Ketut, ( 2004).

Meningkatnya kapasitas usaha dan peran masyarakat di sekitar peternak dalam mengembangkan usaha ternak kambing potong serta memanfaatkan peluang pasar 
ternak seperti usaha jasa, usaha pupuk kandang, usaha pembibitan ternak kambing Fauzi (2012). Pembinaan secara teknis adalah untuk meningkatkan populasi ternak kambing potong, serta meningkatkan produksi dan produktivitas ternak, pembentukan programprogram untuk mengembangan budidaya ternak ruminansia besar dan kecil, yang dapat dilakukan dalam bentuk usaha pengembangbiakan melalui sistem penggemukan atau pembudidayaan serta kombinasi diantara keduanya yang dapat dikembangkan sebagai usaha khusus maupun terintegrasi dengan usaha subsektor lain.

Dengan melihat nilai kontribusi usahatani ternak kambing terhadap pendapatan usaha di sektor pertanian dan peternakan, maka dapat dikategorikan usahatani ternak kambing digolongkan sebagai cabang usaha yang bersifat sambilan. Kecamatan Tinggi Raja Kabupaten Asahan merupakan daerah perkebunan, lahan kosong perkebunan karet dan kelapa, kelapa sawit dan tegalan yang merupakan sumber pakan ternak, seperti rumput gajah, rumput bracilia, gliricia, lamtoro, kaliandra, rumput sawah, rumput raja, rumput lapangan, rumput raket, rumput jampang, dan sisa limbah pertanian seperti dari tanaman jagung, kedelai, kacang tanah, ubi jalar, dan ubi kayu san lain sebagainya. Paat et al. (1992), menyatakan bahwa, usaha ternak kambing di perdesaan dalam pemeliharaannya berkisar antara 3-10 ekor/petani sehingga sulit diharapkan dant berperan sebagai sumber penghasilan pokok bagi petani.

Keberadaan ternak kambing dalam pembudidayaan merupakan modal usaha sehingga dapat menciptakan lapangan kerja bagi penduduk di perdesaan, dan mampu memberikan penghasilan pendapatan bagi petani. Berdasarkan permasalahan tersebut di atas, maka perlu dilakukan penelitian mengenai pendapatan usaha ternak kambing di peternak, disamping usaha pokok tanaman pangan atau yang lainnya. Tujuan tulisan ini adalah untuk melihat sejauh mana peningkatan usaha kambing kelompok tani sumber sari dengan tujuan meningkatkan pendapatan keluarga, serta analisis ekonomi dari usaha pemeliharaan ternak kambing yang diperoleh selama satu tahun dengan menggunakan perhitungan analisis ekonomi pendapatan.

\section{METODE PENELITIAN}

Penelitian dilakukan di Desa Tinggi Raja dan Desa Sumber Harapan di Kecamatan Tinggi Raja Kabupaten Asahan, masing-masing lokasi penelitian mempunyai agroekosistem yang sama. Persamaan dari dua lokasi tersebut mempunyai sumber pakan ternak yang cukup untuk kebutuhan ternak yang mewakili hamparan perkebunan kelapa sawit, perkebunan karet, lahan pertanian dan lahan kosong perkebunan lainnya. Penelitian dilakukan dengan metoda survei dengan mengisi daftar pertanyaan menggunakan kuwesioner dan wawancara berstruktur terhadap 15 responden petani kelompok koopertor dan 15 petani non kooperator, masing-masing desa dalam satu Kecamatan yang dilaksanakan pada bulan Desember 2012, dengan biaya penelitian PIPP Menristek.

Sesuai informasi dari Dinas Penyuluh Pertanian dan Peternakan setempat dengan kriteria populasi ternak kambing. Data primer diperoleh melalui wawancara langsung dengan responden dengan mengacu pada kuesioner, sedangkan data sekunder diperoleh dari Dinas terkait dan hasil penelitian yang telah dilaporkan oleh Kinpscheer (1989) dan Gittinger. (1986), dan Mubiyarto (1989) dalam Bambang. (2009), Doni dan Ericson, (1994) dalam Jemmy et al. (2011), Tikupandang et al. (1995) dan Gittinger, (1986).

$$
\begin{array}{ll}
\mathrm{I} & =\sum(\mathrm{y}-\mathrm{py})-\sum(\mathrm{Xi}-\mathrm{Pi}) \\
\mathrm{I} & =\text { pendapatan }(\mathrm{Rp}) \\
\mathrm{Y} & =\operatorname{output} / \text { hasil }(\text { ternak kambing }) \\
\mathrm{Pxi} & =\text { harga input }(\mathrm{Rp}) \\
\mathrm{Px} & =\text { output }(\mathrm{Rp}) \\
\mathrm{Xi} & =\text { input }(1,2,3 \ldots . . . \mathrm{n})
\end{array}
$$

Analisis dilakukan dengan menggunakan farsial. Indikator analisis yang dipakai adalah R/C ratio (Retun Cost Ratio) Sekarwati (1995)

$$
\begin{aligned}
\text { Jika } & \mathrm{a}>1 \text { maka dikatakan usaha layak } \\
& \mathrm{a}<1 \text { maka dikatakn usaha tidak layak } \\
\mathrm{a}=1 \text { maka dikatakan usaha impas } & \text { tidak untung dan tidak rugi }
\end{aligned}
$$

Sedangkan analisis pendapatan di peroleh dengan cara membandingkan antara pendapatan dan pengeluaran dari komoditas 
ternak yang di kaitkan selama satu tahun atau periode tertentu sesuai usaha yang dijalankan oleh petani.

Produktivitas tenaga kerja (Rp/HOK) menunjukkan besarnya imbalan yang diperoleh peternak yang dicurahkan selama 5 jam kerja (satu HOK), besaran alokasi tenaga kerja dapat dari perhitungan total penerimaan (tunai dan non tunai) selama satu tahun dibagi dengan total curahan tenaga kerja (HOK) selama satu tahun, perlu diketahui petani tidak pernah menghitung biaya tenaga kerja. Besaran produktivitas tenaga kerja dapat dihitung dengan rumus : Rusdiana dan et al., (2009).

Besaran biaya tenaga kerja dapat dihitung dengan rumus

\section{$\mathrm{BTK}=\mathrm{HOK} \times \mathrm{PBR}$}

Keterangan :

BTK $=$ Biaya Tenaga Kerja/tahun

HOK $=$ Curahan tenaga kerja/tahun

Dan HOK dapat dicari dengan rumus :

$$
\mathrm{HOK}=\frac{\sum j a m \times 360}{5} / \text { tahun }
$$

Keterangan : HOK

$\sum$ jam $=$ Jumlah jam kerja buruh tani

$5=5$ jam kerja /hari

$360=$ konversi ke 1 tahun

\section{HASIL DAN PEMBAHASAN}

\section{Kondisi Umum Wilayah}

Penduduk Kabupaten Asahan sebahagian besar bersuku Melayu 75\% sering juga disebut Melayu Asahan atau Melayu Batubara Kabupaten Asahan Sumatera Utara Provinsi Sumatera Utara Ibu kota Kisaran luas 11.431, $\left(114,31 \mathrm{~km}^{2}\right)$. Keadan alam Terdiri dari dataran rendah dan sedikit berbukit, Keadaan tanah liat merah, tanah liat putih bercampur pasir halus Wlayah administratif 7 desa. Jumlah penduduk sekitar 1.038.554 jiwa. Kepadatan penduduk 224,58 jiwa $/ \mathrm{km}^{2}$. Koordinat: $2^{\circ} 59^{\prime} \mathrm{LU}$ 99 $32^{\prime}$ BT. Kabupaten Asahan merupakan salah satu Kabupaten yang berada di kawasan Pantai Timur Sumatera Utara, secara geografis Kabupaten Asahan berada pada 2003'00'$3^{0} 26^{\prime} 00^{\prime \prime}$ Lintang Utara, $99^{0} 01-100^{0} 00$ Bujur Timur dengan ketinggian $0-18 \mathrm{~m}$ di atas permukaan laut. Menempati area seluas 371.945ha yang terdiri dari 13 Kecamatan, 176 Desa/Kelurahan Definitif. Setiap Km2 di Kabupaten Asahan rata-rata dihuni oleh \pm 292,16 ribu jiwa dengan sebaran yang tidak merata pada setiap kecamatan dan terakumulasi di daerah pedesaan.

Wilayah Kabupaten Asahan di sebelah Utara berbatasan dengan Kabupaten Batu Bara, di sebelah Selatan dengan Kabupaten Labuhan Batu dan Toba Samosir, di sebelah Barat berbatasan dengan Kabupaten Simalungun dan di sebelah Timur berbatasan dengan Selat Malaka, Iklim seperti pda umumnya daerahdaerah lainnya yang berada di kawasan Sumatera Utara, Kabupaten Asahan termasuk daerah yang beriklim tropis dan memiliki dua musim yaitu musim kemarau dan musim hujan, Musim kemarau dan musim hujan biasanya ditandai dengan sedikit banyaknya hari hujan dan volume curah hujan pada bulan terjadinya musim. Menurut catatan Stasiun Klimatologi PTPN III Kebun Sei Dadap, pada tahun 2010 terdapat 132 hari hujan dengan volume curah hujan sebanyak $2.150 \mathrm{~mm}$. Curah hujan terbesar terjadi pada bulan September yaitu 342 mm dengan hari hujan sebanyak 12 hari. Sedangkan curah hujan paling kecil terjadi pada bulan Maret sebesar $8 \mathrm{~mm}$ dengan hari 3 hari, rata-rata curah hujan tahun 2010 mencapai $179.17 \mathrm{~mm} /$ bulan.

Konsentrasi pembangunan perekonomian Kabupaten Asahan pada tahun 2011 masih tetap mengarah kepada pembangunan pertanian, infrastruktur, pendidikan, kesehatan dan bidang perekonomian lainnya dan jika dibandingkan dengan kondisi tahun 2008, pertumbuhan ekonomi Kabupaten Asahan pada tahun 2009 mengalami perlambatan. Perlambatan ini diakibatkan oleh adanya penurunan potensi produk komoditi unggulan pada beberapa sector, hal ini terjadi akibat adanya beberapa pergeseran alih fungsi lahan pertanian serta iklim cuaca yang kurang mendukung sehingga hasil yang dicapai tidak maksimal meskipun pemerintah telah melakukan regulasi terhadap kenaikan gaji pada sektor jasa-jasa dan buruh.

Sedangkan sektor ekonomi yang mengalami pertumbuhan adalah sektor perdagangan, hotel dan restaurant, pertumbuhan ekonomi Kabupaten Asahan pada tahun 2009 adalah sebesar 4,67\% mengalami 
S.Rusdiana dan Rijanto Hutasoit : Peningkatan usaha ternak kambing di kelompok ...

Tabel 1. Populasi Ternak Di Kecamatan Asahan

\begin{tabular}{lcccccc}
\hline Desa & Sapi potong & kerbau & domba & kambing & Ayam buras & Itik \\
\hline Tinggi raja & 1371 & 4 & 255 & 294 & 450 & 121 \\
Sumber harapan & 340 & - & 270 & 394 & 3000 & 235 \\
Terusan tengah & 255 & - & 40 & 109 & 225 & 127 \\
Padang sari & 380 & - & 205 & 225 & 345 & 124 \\
Pisaa ulu & 240 & - & 350 & 181 & 325 & 118 \\
Teladan & 406 & - & 106 & 110 & 155 & 155 \\
Sidomulyo & 431 & - & 152 & 372 & 121 & 117 \\
Total & 2423 & 4 & 1378 & 1684 & 5307 & 997 \\
\hline Sumber : Statiustik Kabupaten & Asahan 2011 & & & & &
\end{tabular}

perlambatan sebesar $0,29 \%$ dari kondisi tahun 2008 sebesar $4,96 \%$, terjadinya perlambatan ini bukan hanya semata-mata diakibatkan oleh kebijakan pemerintah daerah, namun juga dipengaruhi oleh kondisi perekonomian nasional dan regional dan bahkan internasional. Beberapa indikator pencapaian kinerja Pemerintah Kabupaten Asahan yang dapat digunakan sebagai tolok ukur dalam menghitung agregat pertumbuhan Satistik Kabupaten Asahan (2011)

\section{Aktivitas Penduduk di Kabupaten Asahan}

Jumlah penduduk Asahan yang merupakan angkatan kerja pada Agustus 2009 adalah sebanyak 292,16 ribu jiwa yang terdiri dari 265,19 ribu jiwa terkategori bekerja dan sebesar 26,97 ribu jiwa terkategori mencari kerja dan tidak bekerja (pengangguran terbuka). Penduduk Asahan yang bekerja ini sebagian besar bekerja pada sektor pertanian yaitu 48,15 persen, Sektor kedua terbesar dalam menyerap tenaga kerja di Asahan adalah sektor perdagangan, hotel dan restoran yaitu sebesar 16,81 persen, sektor lain yang cukup besar peranannya dalam menyerap tenaga kerja adalah sektor jasa-jasa, baik jasa perorangan, jasa perusahaan dan jasa pemerintahan yaitu sebesar 12,13 persen saja, selebihnya bekerja di sektor penggalian dan pertambangan, sektor listrik, gas dan air minum, sektor bangunan, sektor angkutan dan komunikasi, dan sektor keuangan.

Tataguna lahan menunjukkan bahwa perkebunan merupakan bagian terbesar di daerah Tinggi Raja dan menyusul kemudian kebun campuran dan lahan sawah. Keadaan ini menggambarkan bahwa daerah Tinggi Raja adalah lahan perkebunan yang berupa usahatani ternak, sawah, sayur mayur, palawija. Dengan demikian sebagian besar dari penduduk mempunyai mata pencaharian sebagai petani. Disamping usahatani tanaman, usahatani ternak merupakan usaha yang banyak digeluti penduduk. Jumlah dan jenis ternak yang banyak diusahakan adalah ternak sapi, kerbau, kambing, domba, ayam buras, ayam ras, itik, Disnak Statistik Peternakan (2011) terlihat pada Tabel 1.

Pada Tabel 1 terlihat bahwa penguasaan ternak tertinggi pada ternak sapi potong sedangkan kambing peringkat ke 3 (tiga) dari ternak ayam buras Dari data tersebut bahwa Kecamatan Tinggi Raja sangat berpotensi untuk dapat menampung dan menunjang perkembangan sub sektor peternakan khususnya ternak ruminansia dan unggas.

\section{Program Pemberdayaan Petani Melalui Teknologi dan Informasi Pertaian}

Dalam upaya untuk menciptakan sumberdaya manusia secara maksimal dan berperan dalam memberikan informasi serta bimbingan yang dapat yang dapat di terapkan kepada kelompok tani sumber sari, sehingga mampu meningkatkan wawasan dan pengetahuan bagi pertumbuhan ekonomi suatu wilayah, melalui peningkatan kualitas produksi dan produktivitas petani ternak kambing dan tentunya keberhasilan suatu program pertanian dan peternakan tidak terlepas dari adanya program penyuluhan dan pendampingan secara intensif yang ditandai dengan partsipasi aktif dari pelaku utama (petani ternak atau masyarakat sekitar perkebunan) serta pelaku usaha ternak kambing.

Ternak kambing pada umumnya mempunyai umur produksi sekitar 1-4 tahun, dari satu ekor induk kambing akan menghasilkan anak sekitar 2-4 ekor/tahun, bobot badan induk kambing diperkirakan 
sekitar 25-32 $\mathrm{kg}$ bobot hidup. Keberhasilan pembangunan pertanian khususnya komoditi ternak kambing bukan saja ditentukan oleh kondisi sumberdaya alamnya tetapi juga sangat ditentukan oleh peran serta penyuluh, masyarakat dan kualitas sumberdaya manusia (SDM) di pedesaan, penyuluh yang menguasai serta mampu memanfaatkan dan mengembangkan ilmu pengetahuan dan teknologi dalam pengelolaan sumberdaya secara baik saatnya mulai berbenah diri dengan memperhatikan pengalaman masa lalu untuk kembali menata tugas dan fungsinya sebagai pendamping, fasilitator, motivator bahkan sebagai pembawa aspirasi petani atau masyarakat tani (alih teknologi) melalui rekayasa teknologi tepat guna sehingga dapat menjawab tantangan masa kini dan akan datang sesuai amanat Undang-Undang Nomor 16 Tahun 2006 tentang penyuluhan.

Merubah pola usaha pemeliharaan ternak kambing dari tradisional menjadi komersial, adapun orientasi pengembangan sistem teknologi tepat guna disebabkan karena : Luasan lahan untuk usaha ternak kambing masih cukup, harga ternak berfluktuasi. Pemeliharaan ternak kambing tidak ketergantungan pada musim, luas lahan untuk kandang tidak terlalu luas, tidak terlalu membutuhkan tenaga kerja yang banyak, sehingga menjamin efisiensi tenaga kerja dan menekan biaya. Hasil yang diperoleh merupakan produk yang berkualitas dan dapat menembus pasar.

Dari kondisi tersebut, maka Badan Koordinasi Penyuluhan Pertanian dan Peternakan Kabupaten Asahan melaksanakan program egiatan Penyuluhan Penerapan Teknologi Pertanian dan Peternakan Tepat Guna. Komoditi ternak ruminansia besar dan kecil sapi, kambing dan domba di Provinsi Sumatera Utara yang sasaran program pemberdayaan petani melalui teknologi dan informasi petanian (P3TIP-FEATI) meliputi masyarakat kelompok tani sumber sari, penyuluh dan pelaku usaha dalam pengembangan komoditi peternakan di Kecamatan Tinggi Raja dengan 7 (tujuh) desa sudah berlangsung sekitar tahun 2009 s/d sekarang dimana kegiatan yang dilaksanakan berupa kegiatan pembinaan dan sosialisasi, pertemuan-pertemuan dengan petani dan pelaku usaha ternak.

Pembinaan dan pemberdayaan masyarakat kelompok tani sumber sari melalui pendampingan usaha berbasis teknologi untuk komoditas ternak yang berkontribusi dengan penanaman pakan hijaua Brachiaria ruziziensis dan Stylosanthes guianensis di lahan perkebunan kelapa sawit di Kecamatan Tinggi Raja Provinsi Sumatera Utara yang mencakup aspek teknis, organisasi, SDM, Sarana prasarana dan informasi bagi petani serta pelaku usaha secara riil tentang pola penerapan teknologi tepat guna yang efektif dan efisien dalam pengembangan komoditas ternak kambing. Sekaligus sebagai pedoman dan arah dalam melakukan kegiatan penyuluhan dan penerapan teknologi bagi pengembangan komoditas ternak ruminansia serta jumlah kelompok tani sumber sari yang berperan aktif di Kecamatan Tinggi Raja, terlihat terlihat pada Tabel 2.

Tabel 2. Jumlah Kelompok Tani Ternak Menurut Desa Di Kabupaten Asahan

\begin{tabular}{|c|c|c|}
\hline No & Desa & Kelompok tani ternak \\
\hline 1 & Tinggi Raja & 20 \\
\hline 2 & Sumber Harapan & 7 \\
\hline 3 & Terusan Tengah & 12 \\
\hline 4 & Padang Sari & 9 \\
\hline 5 & Pisa Ulu & 12 \\
\hline 6 & Teladan & 11 \\
\hline \multirow[t]{2}{*}{7} & Sidomulyo & 10 \\
\hline & Total & 79 \\
\hline
\end{tabular}

Sumber : Penyuluh Kabupaten Asahan 2011 


\section{Pemanfaat Hijuan Di Lokasi Penelitian}

Lokasi penelitian merupakan daerah perkebunana kelapa sawit, lahan kosong perkebunan karet dan kelapa. Masing-masing lokasi penelitian mempunyai agroekosistem yang sama. Persamaan dari dua lokasi tersebut adalah mempunyai sumber pakan ternak yang cukup untuk kebutuhan ternak. Salah satu jalan diantaranya adalah memasukan ternak tersebut ke areal perkebunan. Daya dukung untuk usaha pemeliharaan ternak selain dipengaruhi oleh agroekosistem dimana daya lahan serta komoditas tanaman yang diusahakan dapat dimanfaatkan oleh ternak sebagai sumber pakan ternak disekitar lingkungan pedesaan.

Hijauan merupakan makanan ternak ruminansia besar dan ekcil, untuk penyediaan hijauan yang berkelanjutan maka pembudidayaan hijauan makanan ternak yang unggul perlu ditingkatkan, adapun hijuan unggul yang sudah banyak di kenal untuk pakan ternak kambing yaitu : rumput gajah, rumput bracilia, gliricia, lamtoro, kaliandra, rumput sawah, rumput raja, rumput lapang, rumput raket, rumput jampang, sisa limbah pertanian dan sebangsanya rurumputan dan yang lainnya. Tanaman pangan seperti : tanaman jagung, kedelai, kacang tanah, ubi jalar dan ubi kayu. Pakan itulah yang sering digunakan pada pemeliharaan ternak kambing yang dilakukan oleh petrani ternak di Kecamatan Tinggi Raja Kabupaten Asahan pakan tersebut di ambil dari kebun, sawah, tegalan, perkebunan kelapa sawit dan lahan kosong yang sengaja di tanaman untuk kebutuhan ternaknya.

Pemeliharaan ternak kambing di Kecamatn Tinggi Taja Kabupaten Asahan dalam beberapa tahun terakhir ini, seluruhnya dilakukan oleh petani kooperator dan petani non kooperator dalam skala pemeliharaan 5-20 ekor petani kooperator sebagai usaha inti sedangakn pemeliharaan skala 1-7 ekot non kooperator sebagai usaha sampingan. Walaupun demikian usaha tersebut sangat nyata dan dapat perhatian dari pemerintah setempat, sebagian peternak memelihara ternaknya dalam kandang dan sebagian melepasnya di padang rumput di lahan perkebuana kelapa sawit atau dilahan sendiri. Sebagaimana di ketahui tujuan utama pemeliharaan ternak kambing untuk meningkatkan kesejahteraan khususnya petani pemilik ternak.

\section{Penguasaan Ternak Kambing Di Petani}

Hamparan lahan kosong (tegalan), lahan perkebunan kelapa sawit dan perkebunan karet yang mana terdapat rumput dan sisa limbah pertanian yang berpengaruh terhadap pertumbuhan ternak kambiung dan semangat petani untuk memelihara ternaknya. Jumlah ternak kambing yang dipelihara oleh petani ternak dari tahun ke tahun relatif tetap. Petani ternak pada umumnya adalah petani kecil yang terbatas penguasaan ternaknya, yaitu 18,2 ekor di Desa Tinggi Raja dan 7,6 di Desa Sumber Harapan. Rataan penguasaan ternak kambing yang dipelihara oleh petani ternak responden baik kooprator maupun non kooperator terlihat pada Tabel 3. Pada Tabel 3 nampak bahwa Desa Tinggi Raja secara persentase status betina dewasa menduduki posisi teratas ratarata 6,2 ekor $(34,06 \%)$ dan Desa Sumber Harapan rata-rata 2,5 ekor $(31,89 \%)$.

Tabel 3. Rata-Rata Penguasaan Ternak Kambing Di Lokasi Penelitian

\begin{tabular}{|c|c|c|c|c|c|c|}
\hline \multirow[t]{2}{*}{ Uraian } & \multicolumn{6}{|c|}{ Lokasi } \\
\hline & \multicolumn{3}{|c|}{$\begin{array}{c}\text { Kooperator } \\
\text { Desa Tinggi Raja (ekor, \%) } \\
n-15\end{array}$} & \multicolumn{3}{|c|}{$\begin{array}{c}\text { Non Kooperator } \\
\text { Desa Sumber Harapan (ekor, \%) } \\
\text { n-15 }\end{array}$} \\
\hline Betina dewasa & 94 & 6,2 & 34,06 & 37 & 2,5 & 31,89 \\
\hline Betina muda & 41 & 2,7 & 14,86 & 16 & 1,0 & 13,79 \\
\hline Betina anak & 29 & 1,9 & 10,50 & 22 & 1,5 & 18,96 \\
\hline Jantan dewasa & 38 & 2,5 & 13,76 & 16 & 1,0 & 13,79 \\
\hline Jantan muda & 39 & 2,6 & 14,13 & 13 & 0,8 & 11,20 \\
\hline Jantan anak & 35 & 2,3 & 12,68 & 12 & 0,8 & 10,34 \\
\hline Jumlah & 276 & 18,2 & 100 & 116 & 7,6 & 100 \\
\hline
\end{tabular}

Sumber data : Analisis data primer 
Hal ini menunjukkan bahwa di Desa Tinggi Raja merupakan petani kooperator sedangkan Desa Sumber Harapan non kooperator (petnai) tetapi kedua Desa tersebut dapat mengembangkan pola usaha pembibitan ternak kambing yang dikembangkan secara tradisional. Sebagai suatu pola usaha pembibitan maka sumber pendapatan utama petani ternak kambing adalah hasil penjualan keturunannya, baik ternak dewasa, muda maupun anak. Peluang untuk memperbesar peranan ternak kambing antara lain adalah dengan memperbesar jumlah induk dan memperbanyak keturunan pada skala pemilikan induk rata-rata 6,2 ekor ekor dan 2,5 ekor maka, seekor induk per tahun dapat menyumbangkan paling sedikit $8 \%$ per tahun dari total pendapatan keluarga.

Dengan demikian jumlah dan produktivitas ternak kambing jantan dewasa dan betina dewasa sangat menentukan besarnya peran usaha ternak dalam struktur pendapatan petani. Namun demikian peranan ternak kambing jantan dan ternak kambing betina merupakan usaha tani dengan kontribusi pendapatan tertinggi, walaupun kenyataannya belum menjadi pusat perhatian petani. Hal ini semakin memperkuat bukti bahwa komponen ternak kambing dalam pemanfaatan lahan kosong (tegalan), perkebunan kelapa sawit dan perkebunan karet lebih kuat dan beradaptasi pada lingkungan disamping komponen tanaman.

\section{Curahan tenaga kerja di petani kambing}

Hasil survai menunjukan bahwa tenaga kerja keluarga yang dicurahkan untuk usaha pemeliharaan ternak kambing di Kecamatan Tinggi Raja Kecmatan Asahan di dua Desa yaitu Desa Tinggi Raja dan Desa Sumber Harapan tidak meningkat secara linier dengan meningkatnya jumlah ternak yang dipelihara 18,2 ekor dan 7,6 ekor ternak kambing relatif sama nampak bahwa tenaga kerja (Rp/Hok/thn) yang dihitung dan di alokasikan untuk usaha pemeliharaan ternak kambing dengan menggunakan waktu 5 jam kerja dihitung 1 (satu) Hok. Dengan pergitungan biaya sebesar Rp.5.000 terlihat pada Tabel 4.

Dari Tabel 4, nampak dari hasil perhitungan tenaga kerja (Rp/Hok/thn) menunjukkan produktivitas tenaga kerja Desa Tinggi Raja sebesar Rp. 1.616.000,-/thn (323,2/Hok/thn) dan Desa Sumber Harapan sebesar Rp. 1.657.000,-/thn $(331,42 /$ Hok/thn) untuk memelihara ternak, sedangkan jenis waktu yang banyak digunakan untuk memelihara ternak kambing Desa Tinggi Raja sebesar Rp.860.000,-/tahun (172/Hok/thn) adalah paling sedikit waktu digembalakan dibandingkan Desa Sumber Harapan sebesar Rp.756.000,-/tahun (151,2,6/Hok/thn) lebih banyak waktu yang digunakan untuk mencari hijauan. Curahan tenaga kerja yang digunakan oleh petani ternak di dua Desa tersebut tidak berpengaruh dalam aktivitas usaha sampingan.

Tabel 4. Rata-Rata Waktu Kerja Petani Usaha Ternak Kambing

\begin{tabular}{|c|c|c|c|c|c|c|}
\hline \multirow[b]{2}{*}{ Jenis pekerjaan } & \multicolumn{6}{|c|}{ Desa Tinggi Raja Kooperator n-15 } \\
\hline & $\begin{array}{l}\text { Jam/ } \\
\text { Hari }\end{array}$ & $\%$ & $\begin{array}{c}\text { rata-rata } \\
n-15\end{array}$ & $\begin{array}{c}\text { thn/hari } \\
(360)\end{array}$ & $\begin{array}{c}5 \text { hok } 1 \\
\text { jam }\end{array}$ & Rp./thn $(5.000,-)$ \\
\hline Mengambil hijauan & 22 & 32,35 & 1,4 & $504 / 5$ & 100,8 & 504.000 \\
\hline Digembalakan & 36 & 52,94 & 2,4 & $860 / 5$ & 172 & 860.000 \\
\hline Perawatan ternak & 10 & 14,70 & 0,7 & $252 / 5$ & 50,4 & 252.000 \\
\hline Jumlah & 68 & 100 & 4,5 & $1.616 / 5$ & 323,2 & 1.616 .000 \\
\hline \multirow[b]{2}{*}{ Jenis pekerjaan } & \multicolumn{6}{|c|}{ Desa Sumber Harapan Non Kooperator n-15 } \\
\hline & $\begin{array}{l}\text { Jam/ } \\
\text { Hari }\end{array}$ & $\%$ & $\begin{array}{c}\text { rata-rata } \\
n-15\end{array}$ & $\begin{array}{c}\text { thn/hari } \\
(360)\end{array}$ & $\begin{array}{c}1 \text { hok } 5 \\
\text { jam }\end{array}$ & Rp./thn $(5.000,-)$ \\
\hline Mengambil hijauan & 32 & 45,7 & 2,1 & $756 / 5$ & 151,2 & 756.000 \\
\hline Digembalakan & 26 & 37,2 & 1,7 & $612 / 5$ & 122,4 & 612.000 \\
\hline Perawatan ternak & 12 & 17,1 & 0,8 & $288 / 5$ & 57,8 & 289.000 \\
\hline Jumlah & 70 & 100 & 4,6 & $1.656 / 5$ & 331,4 & 1.657 .000 \\
\hline
\end{tabular}

Sumber data : Analisis data primer

Keterangan 5 jam kerja dihitung 1 (HOK) Rp. 5.000,- 
Petani ternak tersebut merasa untung, karena petani ternak mempunyai alasan yaitu. Mudah mencari rumput, mudah menjual hasil ternak, mudah memelihara ternak dan kotoran kandang bermanfaat untuk kesuburan tanaman.

\section{Aspek sosial ekonomi di pedesaan}

Pengembanganbiakan ternak kambing merupakan salah satu pendukung dalam pemeliharaan ternak kambing terutama yang berkaitan dengan tujuan memperoleh nilai tambah pendapatan bagi peternak. Salah satu prinsip pengembangbiakan adalah usaha memperoleh keturunan yang berkualitas tinggi sesuai dengan yang diharapkan oleh petani ternak kambing. Pemeliharaan ternak kambing di peternak salah satunya dapat dijadikan sebagai usaha pokok petani (Winarso,2010), berpendapat bahwa ternak kambing dapat memperbaiki kehidupan dan menaikan tingkat gizi para petani dan kesejahteraan keluarga

Aspek sosial terhadap keberadaan ternak kambing merupakan hal penting yang perlu dipertimbangkan. Betapapun baiknya suatu program pengembangan ternak, bila aspek sosial khususnya penerimaan peternak terhadap program tersebut kurang baik, maka program tersebut tidak bermanfaat. Untuk itu segera di dorong kearah suaha yang bersifat komersial baik dari segi harga maupun dari segi pasar.

\section{Perhitungan analisis ekonomi usaha ternak kambing}

Dalam perhitungan analisis ekonomi sederhana yang di lakukan di peternak kooperator dan non kooperator, berdasarkan hasil perhitungan yang akan di mencapai skala ekonomi pada usaha dengan pemeliharaan ternak yang dipelihara minimal adalah 5-20 ekor. Pada penelitian ini skala yang digunakan adalah skala rata-rata 18,2 ekor koopertaor dan skala rata-rata 7,6 ekor non kooperator (petani) yang terdiri dari 6,2 ekor betina induk dan jantan dewasa 2,5 ekor untuk Koopertaoir. Sedangkan Non koopertaor betina dewasa 2,4 ekor dan jantan dewasa 1,0 ekor.

Tabel 5. Analisis Usaha Ternak Kambing Kooperator-Petani (Desa Tinggi Raja)

\begin{tabular}{|c|c|c|c|}
\hline Uraian & $\begin{array}{l}\text { Vol/rata-rata } \\
\text { /ekor/jam/thn }\end{array}$ & $\begin{array}{l}\text { Rata-rata/ } \\
\text { harga (Rp) }\end{array}$ & $\begin{array}{l}\text { Jumlah } \\
\text { ( Rp) }\end{array}$ \\
\hline \multicolumn{4}{|l|}{ A. Biaya Investasi dan Penyusutan } \\
\hline - kandang kambing ( unit) & 1 & 2.507 .500 & - \\
\hline - penyusutan kandang /5 tahun & & & 501.500 \\
\hline - peralatan dan kandang ( paket) & 1 & 215.500 & 215.500 \\
\hline Jumlah & & & 720.000 \\
\hline \multicolumn{4}{|l|}{ B. Biaya variabel } \\
\hline - tenaga kerja keluarga ( HOK) & 323,2 & 5.000 & 1.616 .000 \\
\hline - pakan Konsentrat (kg) & - & - & - \\
\hline - pakan hijauan (kg) & - & - & - \\
\hline - obat-obatan ( Paket) & 1 & 20.000 & 20.000 \\
\hline Jumlah & & & 1.636 .000 \\
\hline Total (A + B) & & & 1.665 .594 .25 \\
\hline \multicolumn{4}{|l|}{ C. Hasil penjualan kambing } \\
\hline -betina dewasa ( ekor) & 6,2 & 739.750 & 4.586 .450 \\
\hline -betina muda ( ekor) & 2,7 & $421.215,72$ & $1.137 .282,44$ \\
\hline -betina anak ( ekor) & 1,9 & 127.241 .93 & $241.759,96$ \\
\hline -jantan dewasa ( ekor) & 2,5 & $1.123 .213,31$ & $2.808 .033,27$ \\
\hline -jantan muda ( ekor) & 2,6 & $501.245,16$ & $1.303 .237,41$ \\
\hline -jantan anak (ekor) & 2,3 & $126.395,81$ & 290.710 .36 \\
\hline Jumlah & 18,2 & - & 10.076 .763 .08 \\
\hline - Pendapatan kotor & & & 10.076 .763 .08 \\
\hline - Pendapatan bersih/tahun & & & $8.411 .168,83$ \\
\hline - Pendapatan bersih/bulan & & & $700.930,73$ \\
\hline$-\mathrm{B} / \mathrm{C}$ & & & 1,4 \\
\hline
\end{tabular}

Sumber data : Analisis data primer

Keterangan :Aanalisis perkiraan keuntungan di hitung berdasarkan hasil penjualan pada tahun 2011-2012 
S.Rusdiana dan Rijanto Hutasoit : Peningkatan usaha ternak kambing di kelompok ...

Tabel 6. Analisis Usaha Ternak Kambing Non Kooperator-Petani (Desa Sumber Harapan)

\begin{tabular}{|c|c|c|c|}
\hline Uraian & Volume & $\begin{array}{l}\text { Rata-rata/ } \\
\text { harga (Rp) }\end{array}$ & $\begin{array}{l}\text { Jumlah } \\
\text { (Rp) }\end{array}$ \\
\hline \multicolumn{4}{|l|}{ A. Biaya Investasi dan Penyusutan } \\
\hline - kandang kambing ( unit) & 1 & 662.366 & - \\
\hline - penyusutan kandang /5 tahun & & & $132.473,2$ \\
\hline - peralatan kandang ( Paket) & 1 & 125.750 & 125.750 \\
\hline Jumlah & & & 258.223 .2 \\
\hline \multicolumn{4}{|l|}{ B. Biaya variabel } \\
\hline - tenaga kerja keluarga ( $\mathrm{HOK}$ ) & 331,4 & 5.000 & 1.657 .000 \\
\hline - pakan Konsentrat (kg) & - & - & - \\
\hline - pakan hijauan (kg) & - & - & - \\
\hline - obat-obatan ( paket) & 1 & 20.000 & 20.000 \\
\hline Jumlah & & & 1.677 .000 \\
\hline Total (A + B) & & & $1.935 .223,2$ \\
\hline \multicolumn{4}{|l|}{ C. Hasil penjualan kambing } \\
\hline -betina dewasa ( ekor) & 1,0 & 724.500 & 724.500 \\
\hline -betina muda ( ekor) & 2,5 & $423.714,28$ & $1.059 .285,7$ \\
\hline -betina anak ( ekor) & 0,8 & $127.071,42$ & $101.657,36$ \\
\hline -jantan dewasa ( ekor) & 1,0 & 1.005 .500 & 1.005 .500 \\
\hline -jantan muda ( ekor) & 0,8 & $512.392,85$ & $409.914,26$ \\
\hline -jantan anak (ekor) & 1,5 & $129.285,71$ & 193.928 .56 \\
\hline Jumlah ( ekor) & 7,6 & - & $3.301 .051,24$ \\
\hline - Pendapatan kotor & & & $3.301 .051,24$ \\
\hline - Pendapatan bersih & & & $1.644 .051,24$ \\
\hline Pendapatan bersih/bilan & & & $137.004,27$ \\
\hline$-\mathrm{B} / \mathrm{C}$ & & & 1,2 \\
\hline
\end{tabular}

Sumber data : Analisis data primer

Keterangan :Aanalisis perkiraan keuntungan di hitung berdasarkan hasil penjualan pada tahun 2011-2012

Penerimaan tunai hanya terkonsentrasi pada penjualan ternak kambing per tahun dan tidak dialokasikan penjualan pupuk kandang, karena semuanya dimanfaatkan untuk pupuk dilahan peternak. Untuk melihat Analisis usaha ternak kambing, yang di hitung berdasarkan penerimaan di kurangi dengan biaya-biaya selama pemeliharaan, hasil perhitungan tercantum pada Tabel 5 dan 6 .

Tabel 5 dan 6, menunjukkan bahwa analisis biaya dan pendapatan dari usaha ternak kambing dapat diasumsikan, bahwa usaha ternak dengan skala 4-10 ekor relatif cukup besar untuk ukuran di perdesaan. Usaha ternak kambing di Desa Tinggi Raja secara Kooperator dengan biaya per tahun Rp.1.665.594.25,- dan usaha ternak kambing di Desa Sumber Harapan secara Non Kooperatorpetani sebesar Rp.1.665.594.25,- sebagian besar untuk biaya tenaga kerja dan penyusutan kandang, sedangkan biaya variabel per tahun untuk usaha Kooperator sebesar Rp.1.636.000,dan usaha Non Kooperator Rp.1.677.000,sebagian besar merupakan biaya pembelian ternak. Pendapatan bersih untuk usaha Koopertor sebesar Rp.8.411.168,83/ tahun, B/C ratio 1,4, dan Non Kooperator sebsar Rp. 1.644.051,24/tahun, $\mathrm{B} / \mathrm{C}$ ratio 1,2 .

Perbedaan hasil pendapatan di Desa Tinggi Raja pemeliharaan secara Kooperator dan di Desa Sumber Harapan pemeliharaan secara Non Kooperator dalam penyediaan hijauan pakan ternak sudah ada di lahan perkebunan kelapa sawit seluas 3 ha dan dapat bimbingan khusus dari penyuluh pertanian dan peternakan setempat sedangkan Non Kooperator adalah sebagai petani sendiri tanpa ada sentuhan teknologi dan pakan hijauan mengandalkan dari lahan petani sendiri. Pendapatan dari usaha pemeliharaan ternak kambing baik secara Kooperator maupun Non Kooperator tidak berbeda jauh dengan hasil penelitian UTOMO et al., (2005) dengan pendapatan bersih Rp.2.372.960/tahun dengan pemeliharaan ternak kambing 8 ekor betina dan 1 ekor pejantan selama satu tahun. 


\section{KESIMPULAN DAN SARAN}

Kecamatan Tinggi Raja Kabupaten Asahan Desa Tinggi Raja dan Desa Sumber Harapan memiliki potensi untuk pemeliharaan ternak kambing potong yang dapat meningkatkan pendapatan keluarga, disamping usaha pokok tanaman pangan. Pemeliharaan ternak kambing secara ekonomi memberikan keuntungan yang dpat meningkatkan kesejahteraan petani ternak di pedesaan. Pendapatan bersih untuk usaha kambing secara Koopertor sebesar Rp.8.411.168,83/tahun, B/C ratio 1,4 , dan usaha kambing secara Non Kooperator sebsar Rp.1.644.051,24/tahun, B/C ratio 1,2 .

Berdasarkan hasil penelitian yang diperoleh, disarankan kepada pemilik pemodal atau pengusaha ternak kambing di Kabupaten Asahan dapat mempertahankan kelompok tani ternak Sumber sari sehingga mampu memperluas pemasaran ternak kambing juga penambahan populasi kambing. Selain itu dapat meningkatkan pendapatan yang lebih baik dan dapat memperluas usaha ternak kambing secara komersial dari skala kecil ke menengah dan mampu bersaing di pasar luas.

Peluang untuk memperbesar peranan ternak kambing antara lain adalah memperbesar atau memperbanyak jumlah induk pada sistem pemeliharaan, maka seekor induk per tahun bisa menyumbangkan sepuluh persen dari keturuna dari total pendapatan keluarga per tahun, memperpendek jarak kelahiran dengan jalan menggunakan paket teknologi perkawinan secara intensif dan pemisahan anak juga dapat menaikan peran ternak kambing dalam menopang pendapatan keluarga.

\section{DAFTAR PUSTAKA}

Amir.P and Kinpscher.H.C. 1989. Conducting On Farm Animal Research Procedures and Economic Analysis. Singapore National Printer Ltd, Singapore 1989

Bamualim.A. 2010. Pengembangan teknlologi pakan sapi potong di dearh semi arid Nusa Tenggara. Orasi Pengukuhan Profesor Riset Bidang Pemuliaan Ruminansia (Pakan dan Nutrisi Ternak). Badan Penelitian dan Pengembangan
Pertanian Kemnetrian Pertanian Bogor, 29 Nopemebr hal. 1-59.

Bambang.R. Prawiradiputra. 2009. Masih adakah peluang pengembangan integrasi tanaman dengan ternak di Indonesia. Wartazoa. vol.19. No.3 September 2009 hal, 143-155

Boediono. 1983. Ekonomi Mikro Pertaniana Edisi II BPFE. Jakarta 21983

Fauzi Luthan 2012. Budidaya Kambing untuk Dijadikan Acuan Bagi Para Pelaksana Kegiatan Laporan Realisasi Perkembangan Kegiatan dan Penggunaan Uang. Disahkan oleh tim teknis. www/Deptan.go.id/Pedum2012/./1.3.Jen is File: PDF/Adobe Acrobat- Tampilan Cepat. Tanggal 7 Juli 2013

Gittinger.J.P. 1986. Analisis Ekonomi ProyekProyek Pertanian. Edisi Kedua. Universitas Indonesia. Jakarta.

Jemmy Rinaldy I. K.I M.R. 2011. Analisis kelayakan dan kontribusi pendapatan usahatani komoditas tanaman pangan dan palawija dilahan kering dataran rendah Balai Pengngajian Teknologi Pertanian Bali. 23 Nov $2011 \quad$... kelayakan usahatani yaitu $\mathrm{R} / \mathrm{C}$ ratio dan analisis ekonomi Pengkajian Sistem Usahatani Tanaman dan Ternak di Lahan www.docstoc.com/.../analisis kelayakan Tembolok - Mirip., tanggal 25 Maret 2012

Ketut Sutama.I. 2004. Tatangan dan Peluang Peningkatan Produktivitas Kambing Melaui Inovasi Teknologi Reproduksi. Prosiding Lokarya Nasional Kambing Potong, Pusat Penelitian dan Pengembangan Peternakan bogor, 6 Agustus 2003, hal, 51-60

Rusdiana.S., dan Ratna Ayu.S. 2009. Kontribusi Tanaman Ubi Kayu dan Ternak Kambing Terhadap Pendapatan Petani: Analisis ekonomi (Kasus di Kota Bogor). Prosiding Seminar Nasional Teknologi Peternakan dan Veteriner. Pusat Penelitian dan Pengembangan Peternakan Bogor, Badan Penelitian dan Pengembangan Pertanian, kementerian 
Pertanian, Bogor 13 -14 Agustus 2010. hal 507-514

Paat.P.C.B.Seriadi.B., Sudaryanto dan Saribuang. 1992. Peranan Usaha Ternak Kambing Peranakan Ettawah dalam Sistem Usahatani di Boggae Majene Pros. Saresehan Usaha Ternak di Kambing dan Domba Menyongsong Era PJTP II, hal, 162-165

Soekarwati, A.Soehardjo, J.L. Dillon, and J.B. Hardaker. 1994. Ilmu Usahatani dan Penelitian untuk Pengembangan Petani Kecil di Pedesaan. UI Press. 1994 Jakarta.

Seokarwati. 1995. Analisis usahatani. Penerbit Universitas Indonesia (UI Press-Jakarta, 1995)

Statistik Pertanian. 2010. Departemen Peranian Repubulik Indonesia. Pusat Data dan Informasi Pertanian. Departemen Pertanian.

Satistik Kabupaten Asahan 2011. Dalam Angka Sementara. Dinas Penyuluh Pertanian dan Peternakan Kabupaten Asahan. 2011

Syamsu.J.A., Lilya.A., Sosyan.,K.Mudikdjo dan E.Gumilar.S. 2003. Daya Dukung Limbah Pertanian Sebagai Sumber Pakan Ternak Ruminansia di Indonesia. Jurnal Wartazoa Volume 13 tahun 2003. Hlm 32-37.

Saenab. S., dan Waryat. 2005. Strategi Pengembangan Tanaman Pakan Ternak Diwilayah Perkotaan. Prosiding Lokakarya Nasional Tanaman Pakan Ternak. Bogor 16 September 2005. hal. 83-36.

Simon.Ginting. 2010. Beberapa Alternatif Skema Percepatan Perkembangan dan Penyebaran Bibit Kambing Boerke. Prosiding Seminar Nasional Membangun Sistem Inovasi di Perdesaan. Balai Besar
Pengkajian dan Pengembangan Teknologi Pertanian Bogor, 15-16 oktober 2009. Buku I. Hal. 246-255.

Tatang.M.I.2003. Strategi Penelitian Hijauan Mendukung Pengembangan Ternak Kambing Potong di Indonesia. Wartazoa Buletin Ilmu Peternakan Indonesia, Pusat Penelitian dan Pengembangan Peternakan Bogor, Vol. 13 No.1 Tahun 2003, hal 22-29

Tikupandang.A.A. Prabowo dan D. Sugandi. 1995. Aspek Tenaga Kerja Kelurga dalam Sistem Usahatani Ternak Terpadu di Daerah Transmigran Sulawesi Selatan. Prosiding Seminar Nasional Sains dan Teknologi Peternakan Pengelolaan dan Komunikasi Hasil-hasil Penelitian. Balai Penelitian Ternak Ciawi-Bogor, hal. 539-545.

Utomo.U.,T. Herawati dan S.Prawirodigdo. 2005. Produktivitas Induk Dalam Usaha Ternak Kambing Kondisi Pedesaan. Prosiding Seminar Nasional. Teknologi Peternakan dan Veteriner, Pusat Penelitian dan Pengembangan Peternakan Bogor, 12-13 September 2005, hal. 660-665

Winarso.B.2010. Prospek dan Kendala Pengembangan Agribisnis Ternak Kambing dan Domba di Indonesia. Prosiding Seminar Nasional. Peningakatan Daya Saing Agribisnis Berorientasi Kesejahteraan Petani. Pusat Analisis Soasial Ekonomi dan Kebijakan Pertanian Kementrian Pertanian, hal. 246-264

Yusdja, Y. 2004. Prospek usaha peternakan kambing menuju 2020, Pros Lokakarya Nasional Kambing Potong. Pusat Penelitian dan Pengembangan Peternakan, Bogor. Hal, 21-27. 